\title{
Psychosurgery supporters sued for malpractice
}

\section{David Dickson reports from Boston on a little-publicised court case that has revived debate on the psychiatric use of surgery}

Two prominent supporters of the use of surgery to control the behaviour of individuals are being sued for malpractice by a former patient who, it is claimed, is now confined to a mental hospital as a direct result of the treatment that he received.

The charge of negligent treatment has been made against Dr Vernon $\mathrm{H}$. Mark, Director of the Neurosurgical Service at Boston City Hospital, and Associate Professor of Surgery at Harvard Medical School, and Dr Frank R. Ervin, now Professor of Psychiatry at the University of California in Los Angeles.

Dr Mark and Dr Ervin became the centre of a fierce public controversy in 1967 when, in a letter to the Journal of the American Medical Association, written with Dr William H. Sweet, Professor of Surgery at Harvard Medical School, they suggested that brain dysfunction in individuals might have contributed to the urban riots that swept several American cities in the late 1960s-and that people with 'low violence thresholds' should therefore be diagnosed and treated before they contributed to further such tragedies.

Three years later, Drs Mark and Ervin published a book Violence and the Brain in which they wrote that they intended to stimulate a "new biologically-oriented approach to the problem of human violence" and that this should lead to a "more rational approach" to the problems of violence.

The suit claiming malpractice has been filed by the mother of $\mathrm{Mr}$ Leonard A. Kille, previously a research and development engineer with the Polaroid Corporation. It is being handled by the Washington law firm on which Health Secretary, Mr Joseph Califano, was once a senior partner.

While working for Polaroid, $\mathrm{Mr}$ Kille headed a team that was responsible for a number of patents on the land camera. He received treatment, including brain surgery, from the two defendants in 1966 and 1967 and he is generally taken to be the patient 'Thomas R.' described in Violence and the Brain as a "brilliant 34-year-old engineer with several patents to his credit", whose treatment Dr Mark and Dr Ervin say represented the first time they were able to demonstrate that systems in the limbic brain both start and stop attack behaviour.

According to evidence presented to a jury which is currently considering the charges in a Boston court-room, $\mathrm{Mr}$ Kille was referred to the Boston
General Hospital in 1966 after a history of epileptic seizures and outbursts of violent behaviour mainly directed towards his wife. He was diagnosed as having psychomotor seizures and 'personality pattern disturbance', and subsequently as suffering from temporal lobe epilepsy.

Following apparently unsuccessful attempts by the hospital to treat him with a variety of drugs, Dr Mark and Dr Ervin implanted a series of electrodes in his brain, the stimulation of certain of which relieved his aggressive symptoms. They subsequently performed an operation by making small bilateral lesions in his medial amygdala through heating the electrodes.

Immediately after the operation, according to evidence presented in the court, Mr Kille's behaviour seemed to have improved. At one point for example, he said that he 'felt like a new person'. However, shortly after his release from hospital his violent tendencies returned, and a month later he was admitted to a west coast hospital where he was described as "hallucinated, delusional and confused" and diagnosed as schizophernic and paranoid.

A succession of hospitalisations and subsequent discharges followed, with continued signs of aggressiveness and belligerence. $\mathrm{Mr}$ Kille was eventually placed under permanent care at the Bedford Veterans Administration hospital, 25 miles north of Boston, where he is now confined. In the suit that has been filed on his behalf, it is now claimed that he was "rendered of unsound and unbalanced mind" as a direct result of negligent treatment by Dr Mark and Dr Ervin.

In particular, it is alleged that the surgeons failed to inform him fully of the risks and ramifications of the surgical procedures that they were recommending, and that they therefore failed to obtain his informed consent. A charge of battery resulting in permanent injury and incapacitation has been made and damages of $\$ 2$ million are being sought.

During the court proceedings, the plaintiffs have claimed that the surgeons considered that they were treating a behavioural, rather than a medical, condition (in their book they describe T. R.'s chief problem as being his violent rage), and that although the procedures they were adopting should have been described to $\mathrm{Mr}$ Kille and his wife as experimental this was not in fact done.
Suggesting that there might also have been a conflict of interest between medical and scientific priorities, the plaintiffs have pointed out that $\mathrm{Dr}$ Mark told a neuroscience seminar in December 1966 that inserting electrodes in the brain for therapeutic reasons served a dual purpose since it had "real value both to the patient and to our scientific enquiry".

They have also quoted a passage from a later printing of Violence and the Brain in which Dr Mark and Dr Ervin state that "four years have passed since the operation, during which Thomas has not had a single episode of rage. He continued, however, to have an occasional epileptic seizure with periods of confusion and disordered thinking". This indicates that the surgeons were primarily concerned with altering their patient's behaviour rather than his medical condition--and that they felt they had successfully treated the former.

The defendants have replied to the various charges by saying that $\mathrm{Mr}$ Kille was diagnosed as suffering from temporal lobe epilepsy, which gave rise to his seizures, and that given the state of medical knowledge at the time, as well as the patient's failure to respond to more conventional treatment, the surgical procedures that they took were appropriate.

They also claim that during the meeting at which $\mathrm{Mr}$ Kille and his wife formally gave their consent to the amygdalectomy operation, it was explained that there was roughly a onethird chance that the operation would successfully relieve his symptoms, a one-third chance that there would be some improvement, and a one-third chance that there would be no improvement or a deterioration.

Finally responding to the published description of the patient T.R., Dr Mark told the jury that this was a composite case history with detail taken from a number of patients, and that it should not be taken as describing exactly the case of $\mathrm{Mr}$ Kille.

The whole case has revived the debate on the ethics of psychosurgery which flourished at the beginning of the decade. Two years ago, following widespread public concern on the issue, the National Commission for the Protection of Human Subjects of Biomedical and Behavioural Research issued a report which, to the surprise and disappointment of some and the delight of others, gave psychosurgery its approval in some circumstances.

Though professing to an initial scepticism, the report drew on studies showing that a large number of 
patients had been successfully relieved of pain or depressive symptoms as a result of such surgery to support the contention that it was a potentially beneficial therapy.

Others still claim, however, that although psychosurgery may be effective in alleviating symptoms such as pain and depression, this is frequently at the expense of sacrificing other aspects of the individual's identity, such as emotional responsiveness and creativity. It is also claimed that the psychosurgeons approach reduces social behaviour to a purely biological phenomenon, thus denying a range of environmental factors which alternative forms of treatment, such as psychotherapy, can take into account.

"There is no scientific foundation for attempting to control a specific aspect of social behaviour by destroying a portion of the human brain", says Dr Stephan Chorover, Professor of Psychology and Brain Science, at the Massachusetts Institute of Technology, who has given evidence during the court hearings. "The main thrust of this approach to social problem solving is that it tries to localise the problem in 'defective individuals' and therefore embodies a decision not to search for problems in the larger social system".

Whichever way the court decision goes, it is unlikely to resolve the wider philosophical issues surrounding the use of psychosurgery, since the matters on which the jury has been asked to judge relate essentially to the adequacy of the medical procedures followed prior to and during the treatment.

At the same time, however, it could provide a precedent for further legal actions. Already a second case is being brought on behalf of a girl who, at the age of 19 but without her consent, and after a series of electric shock treatment but minimal psychotherapy, had a cingulotomy-a lesion of the cingulum-performed by another Boston surgeon. This case is scheduled to be heard shortly.

\section{Scientist may sue over}

THE Supreme Court has agreed to rule on whether Senator William Proxmire committed libel when he made a "Golden Fleece" award to a scientist engaged in a study for NASA of teeth-clenching by monkeys.

Senator Proxmire, who is chairman of the Senate Appropriations Subcommittee responsible for the budgets of both NASA and the National Science Foundation, has frequently made such awards to esoteric- or naive-sounding research projects, which he claims to be an unncessary drain on the public purse. One recipient of the award was a research scientist, $\mathrm{Dr}$ Ronald $\mathrm{R}$.

\section{More dangerous smallpox labs?}

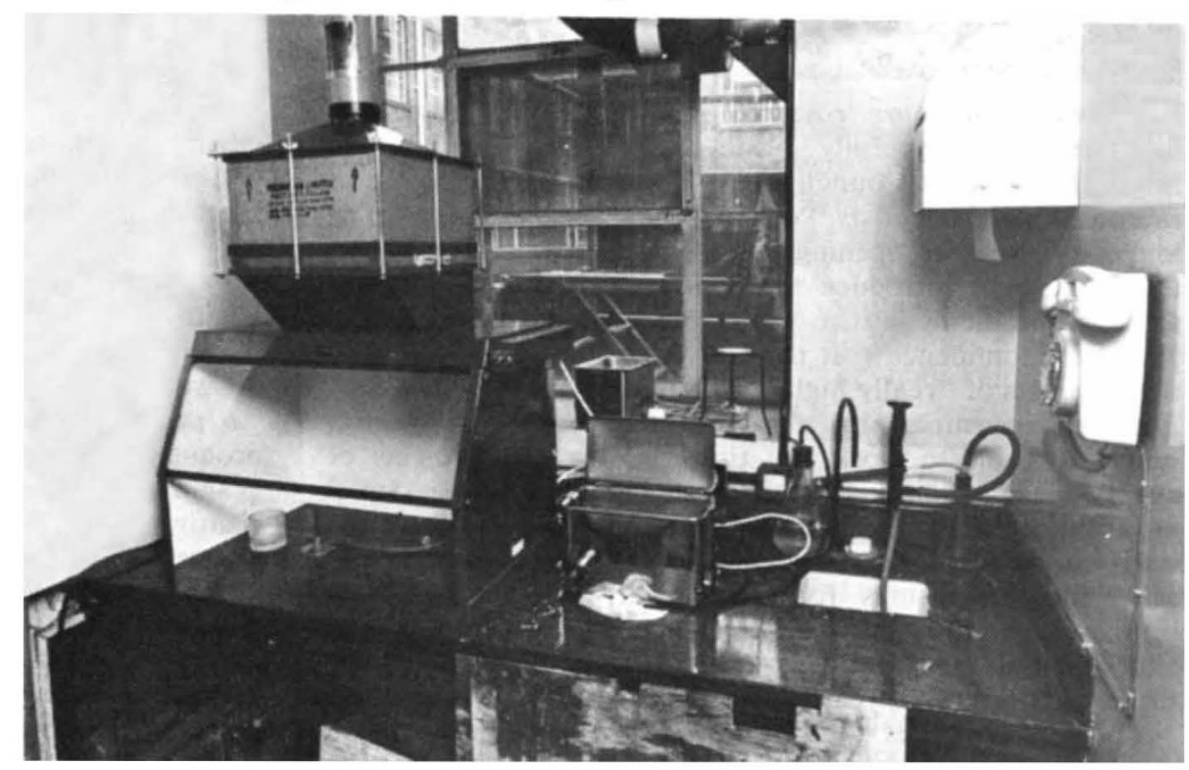

Above: the smallpox laboratory at Birmingham University from which the virus escaped last August. A possible route of infection-through a cable duct-appears bottom left.

As FAR as the World Health Organisation (WHO) is aware there are now nine laboratories in the world holding live smallpox virus; but only three of them-those in London, Hamburg and Atlanta-are known to match up to WHO smallpox laboratory safety recommendations. The laboratories at St Mary's Hospital, London and the Centre for Disease Control, Atlanta are to become WHO collaborating centres for poxvirus research; so is the Research Institute of Viral Preparations, Moscow, which is currently making modifications to come up to the WHO standard.

The Institut fur Schiffs und Tropenkrankheiten in Hamburg, the Rijks Institut voor de Volksgezondheid, Bilthoven, the Netherlands, the US Army Medical Research Institute for Infectious Diseases and the American Type Culture Collection are all considering either destroying or transferring their viruses to one of the WHO collaborating centres. The latter three labora- tories have not been visited by WHO. The other two laboratories currently holding smallpox virus are in Peking (which WHO has no plans to visit) and South Africa, which does not come up to standard, is storing the virus, but doing no research. Only the Centre for Disease Control in Atlanta is doing smallpox research at the moment.

The risks of laboratory infection should be seen in proportion, however. The WHO smallpox eradication unit has reduced the death rate from the disease from one million per year 10 years ago to probably zero this year. And smallpox is not an easily transmitted disease : it is not as infectious as flu or measles, for example.

- Correction: six white coats per laboratory worker were recommended by the Howie report on a code of practice for the prevention of infection in clinical laboratories, not the Godber report on the handling of dangerous pathogens, as indicated in last week's leader.

\section{"Golden Fleece" award}

Hutchinson, of Kalamazoo, Michigan, who, according to $\mathrm{Mr}$ Proxmire, has received more than $\$ 500,000$ in federal funding for research that includes measuring the latent aggression of laboratory monkeys under various conditions by recording electrical impulses in the jaw muscles.

Although NASA has said that the work was of particular importance in its efforts to identify aggressive personality traits in selecting crews for long space flights, Mr Proxmire called the research an outrageous example of "wasteful, extravagant, stupid spending".
A lower court rejected a libel action for $\$ 8$ million brought by the research worker partly on the grounds that he had become a "public figure" by soliciting government grants and publishing occasional articles in professional journals. Senator Proxmire also claimed legislative privilege. The Supreme Court has now agreed to hear an appeal from Dr Hutchinson, who claims that, as a result of the award, he has suffered injury to his reputation. illness, mental anguish and prospective loss of economic advantage. 